\title{
Inhibition of HSP90 Promotes Neural Stem Cell Survival from Oxidative Stress through Attenuating NF- $\kappa$ B/p65 Activation
}

\author{
Qian Liu, ${ }^{1,2}$ Yun Li, ${ }^{1}$ Wenkai Jiang, ${ }^{2,3}$ Yunzi Li, ${ }^{1}$ Lin Zhou, ${ }^{4,5}$ Bing Song, ${ }^{2}$ and Xinfeng Liu ${ }^{1}$ \\ ${ }^{1}$ Department of Neurology, Jinling Hospital, Medical School of Nanjing University, 305 East Zhongshan Road, Nanjing, \\ Jiangsu 210002, China \\ ${ }^{2}$ School of Dentistry, Cardiff Institute of Tissue Engineering and Repair, Cardiff University, Heath Park, Cardiff CF14 4XY, UK \\ ${ }^{3}$ State Key Laboratory of Military Stomatology \& National Clinical Research Centre for Oral Diseases \& Shaanxi Key Laboratory of \\ Oral Diseases, Department of Operative Dentistry \& Endodontics, School of Stomatology, Fourth Military Medical University, \\ No. 145 Western Changle Road, Xi'an, Shaanxi 710032, China \\ ${ }^{4}$ Department of Chemistry \& Chemical Biology, MSC03 2060, University of New Mexico, Clark Hall B58, Albuquerque, \\ NM 87131-0001, USA \\ ${ }^{5}$ College of Chemistry and Materials Science, Jiangsu Key Laboratory of Biofunctional Materials, Nanjing Normal University, \\ Nanjing 210023, China
}

Correspondence should be addressed to Bing Song; songb3@cardiff.ac.uk and Xinfeng Liu; xfliu2@vip.163.com

Received 8 June 2016; Revised 23 August 2016; Accepted 25 August 2016

Academic Editor: Javier Egea

Copyright ( 2016 Qian Liu et al. This is an open access article distributed under the Creative Commons Attribution License, which permits unrestricted use, distribution, and reproduction in any medium, provided the original work is properly cited.

\begin{abstract}
Stem cell survival after transplantation determines the efficiency of stem cell treatment, which develops as a novel potential therapy for several central nervous system (CNS) diseases in recent decades. The engrafted stem cells face the damage of oxidative stress, inflammation, and immune response at the lesion point in host. Among the damaging pathologies, oxidative stress directs stem cells to apoptosis and even death through several signalling pathways and DNA damage. However, the in-detail mechanism of stem cell survival from oxidative stress has not been revealed clearly. Here, in this study, we used hydrogen peroxide $\left(\mathrm{H}_{2} \mathrm{O}_{2}\right)$ to induce the oxidative damage on neural stem cells (NSCs). The damage was in consequence demonstrated involving the activation of heat shock protein 90 (HSP90) and NF- $\kappa \mathrm{B} / \mathrm{p} 65$ signalling pathways. Further application of the pharmacological inhibitors, respectively, targeting at each signalling indicated an upper-stream role of HSP90 upon NF- $\kappa$ B/p65 on NSCs survival. Preinhibition of HSP 90 with the specific inhibitor displayed a significant protection on NSCs against oxidative stress. In conclusion, inhibition of HSP90 would attenuate NF- $\kappa \mathrm{B} / \mathrm{p} 65$ activation by oxidative induction and promote NSCs survival from oxidative damage. The HSP90/NF$\kappa \mathrm{B}$ mechanism provides a new evidence on rescuing NSCs from oxidative stress and also promotes the stem cell application on CNS pathologies.
\end{abstract}

\section{Introduction}

Stem cell transplantation is considered as a novel potential therapy for several central nervous system (CNS) diseases through both growth/trophic factor support and neural cell replacement [1-3]. However, the dramatic number of cell death after transplantation due to oxidative stress, inflammation, and immune response in lesion limits the therapy for wide application [4-7]. To increase the stem cell survival after transplantation, strategies against the above damaging pathologies are investigated in recent decades [8].
Among the damaging pathologies, oxidative stress is considered as a primary vital damaging factor to engrafted stem cells. The pathology directs the stem cells to produce extra reactive oxygen species (ROS), which could trigger several of intracellular signalling cascades, thus leading to DNA damage and cell apoptosis and even death [9]. Therefore, study on the underlying signalling mechanism in oxidative stress could provide some evidence to rescue the engrafted stem cells from damage. Previous study of ours reported the mediating role of $\mathrm{NF}-\kappa \mathrm{B} / \mathrm{p} 65$ in neuronal protection against oxidative stress [10] while both whether this signalling 
transduction also applies on NSCs survival and the pathway from oxidative stimulation to NF- $\kappa \mathrm{B} / \mathrm{p} 65$ activation in NSCs have not been investigated before.

In this study, we investigated the role of heat shock protein 90 (HSP90) and NF- $\kappa \mathrm{B} / \mathrm{p} 65$ in neural stem cells (NSCs) under induced oxidative injury, as well as their relationship during the pathology. According to our results, oxidative stress firstly triggers HSP90 in stimulated NSCs. The triggered HSP90 in consequence activates NF- $\kappa \mathrm{B} / \mathrm{p} 65$ through $\mathrm{IKK} / \mathrm{I} \kappa \mathrm{B} / \mathrm{p} 65$ cascade, which leads finally to cell death. Inhibiting HSP90 activity will block the downstream activation of NF- $\kappa \mathrm{B} / \mathrm{p} 65$ under oxidative stress and increase NSCs survival. The HSP90/NF- $\kappa$ B mechanism might rescue NSCs from oxidative stress and also promotes the stem cell study and application on CNS pathology.

\section{Material and Methods}

2.1. Reagents. DMEM/F12, B27 supplement, EGF, bFGF, Penicillin/Streptomycin, Accutase, Poly-D-lysine (PDL), and Annexin V-FITC/PI kit were purchased from Thermo Fisher Scientific (San Jose, CA, USA). Hydrogen Peroxide $\left(\mathrm{H}_{2} \mathrm{O}_{2}\right)$, DMSO, Geldanamycin (GA), JSH-23, and MTT were purchased from Sigma-Aldrich (St. Louis, MO, USA). All primary antibodies used in this study were purchased from Cell Signalling Technology (Danvers, MA, USA). Goat antirabbit/mouse IgG (H+L) Alexa Fluor ${ }^{\circledR} 488 / 594$ and HRP conjugate secondary antibodies were purchased from Thermo Fisher Scientific (San Jose, CA, USA). Hoechst 33342 and DCFH-DA probe were purchased from Beyotime Biotech (Haimen, China).

2.2. Neural Stem Cell Culture. All experiments were carried out in accordance with Animals (Scientific Procedures) Act 1986 under project license 30/2816 issued by UK Home Office. This study was approved by Jinling Hospital Research Ethics Committee. C57BL/6 mice were housed in a temperaturecontrolled environment $\left(22 \pm 0.5^{\circ} \mathrm{C}\right)$ with a 12 -h light-dark cycle and allowed free access to food and water. All efforts were made to minimize animal suffering and reduce the number of animals used. The NSCs were dissected from embryonic brain tissue of E14 day C57BL/6 mice (mice were provided by Model Animal Research Centre of Jingling Hospital Nanjing, Jiangsu, China). Briefly as described previously [11], the brain tissue was transferred into ice bathed DMEM/F12 medium for meninx and vessel tissue removal. The brain tissue was then digested by Accutase. The singlecell suspension was collected and resuspended in DMEM/F12 medium containing B27, bFGF, and EGF. The cell culture was kept in at $37^{\circ} \mathrm{C}, 5 \% \mathrm{CO}_{2}$. Changing culturing medium was done every three days. Passage of the NSCs was performed as the neurospheres grew to $50-100 \mu \mathrm{m}$ diameter.

2.3. NSCs Oxidative Stress Induction. The neurosphere culture was digested into single-cell suspension and seeded on the PDL precoated cover glass, dish, or 6-well plates, depending on further test. The NSCs were cultured at $37^{\circ} \mathrm{C}$, $5 \% \mathrm{CO}_{2}$ overnight. As far as the single cell of NSCs attached, change the medium with DMEM/F12 medium without B27, EGF, and bFGF for cell starving, preparing the following oxidative stress induction.

Following $2 \mathrm{~h}$ starving, 50, 100 (final applied moderate concentration for modelling), 200, and $400 \mu \mathrm{M} \mathrm{H}_{2} \mathrm{O}_{2}$ were, respectively, added to DMEM/F12, culturing for further $2 \mathrm{~h}$ as the oxidative stress induction, to choose the final modelling dosage. DMEM/F12 medium without any supplements was used as the vehicle control.

2.4. NSCs Treatment. For the signalling inhibitor pretreatment, after the cell starving, $0.5 \mu \mathrm{M}$ (final concentration) GA and $8 \mu \mathrm{M}$ (final concentration) JSH-23 were administrated, respectively, to the monolayer NSCs for $1 \mathrm{~h}$, before the oxidative stress induction. DMSO was used as the cosolvent, with the final concentration of $0.1 \%$. DMEM/F12 medium containing $0.1 \%$ DMSO was used as the vehicle control.

2.5. Cellular Detection. The cell viability was assessed with MTT assay as previously described [10]. The intracellular reactive oxygen production was detected with the DCFHDA probe dye, according to the manuscript's instructions. The apoptosis and cell death assessment were detected with Annexin V-FITC/PI kit following the manuscript's instructions.

2.6. Immunofluorescence (IF). The NSCs were fixed with $4 \%$ paraformaldehyde (Sigma-Aldrich, MO, USA) and permeabilized with $0.1 \%$ Triton X-100 (Sigma-Aldrich, MO, USA). After blocking the nonspecific proteins with 3\% BSA-PBS solution, the fixed cells were then incubated with anti-HSP90 and anti-phospho-p65 over night at $4^{\circ} \mathrm{C}$. The cells were transferred to FITC/TRITC-conjugated secondary antibodies (Cell Signalling Technology, MA, USA), incubating for 1 hour. Fluorescence data was collected with fluorescence microscope and analyzed with ImageJ software.

2.7. Western Blotting. The cell lysate was collected from NSCs. The sample loadings were subjected onto $12 \%$ SDS-PAGE gel for electrophoresis as previously described with slight modification [10]. The protein bands were transblotted onto PVDF membrane (Millipore, OH, USA), being blocked in 5\% BSA-TBST buffer and incubated with the primary antibodies and HRP-conjugated secondary antibodies. The antigenantibody complexes were then detected with an ECL reagent kit (Millipore, OH, USA), and developed with X-ray film. The protein band density was analyzed with ImageJ software.

2.8. Statistical Analysis. We evaluated the statistical significance using independent-samples $t$-tests, followed by ANOVA tests when the data involved three or more groups. Results are presented as means \pm SD. $P<0.05$ was considered to be significant.

\section{Results}

3.1. Culture of Neural Stem Cells. The NSCs were dissected from embryonic mouse at E14 and cultured to form the 

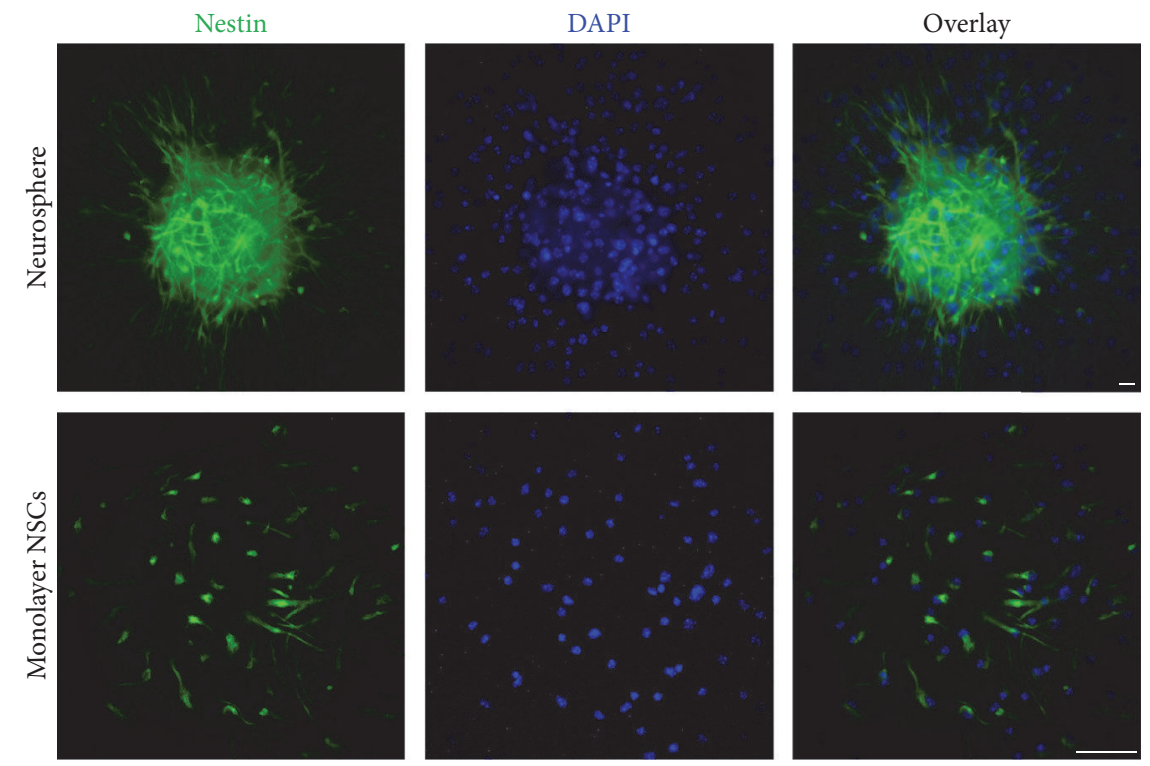

FIGURE 1: Identification of NSCs. Immunofluorescence identification of neurosphere and monolayer culture of NSCs with anti-Nestin. Scale bar: $20 \mu \mathrm{m}$.

neurospheres in flasks. For cell identification, immunofluorescence targeting at the Nestin was applied (Figure 1). As the result demonstrated, up to $\sim 95 \%$ cells were detected as Nestin-positive NSCs.

\subsection{Oxidative Stress Induced Cell Death in Neural Stem Cells.}

The monolayer culture of NSCs was subjected to $100 \mu \mathrm{M}$ $\mathrm{H}_{2} \mathrm{O}_{2}$ treatment for $2 \mathrm{~h}$. After oxidative stress induction, the cell morphology, MTT assay, DCF-DA, and Annexin VFITC/PI staining were applied to assess the cell injury.

According to the results with 50,100, 200, and $400 \mu \mathrm{M}$ $\mathrm{H}_{2} \mathrm{O}_{2}$ treatment (Figure 2(a)), the injury with $100 \mu \mathrm{M} \mathrm{H}_{2} \mathrm{O}_{2}$ was the moderate dosage to NSCs (cell viability proportion dropped to $50.2 \pm 6.3 \%$ ). While $50 \mu \mathrm{M} \mathrm{H}_{2} \mathrm{O}_{2}$ induced a very light injury, 200 and 400 induced too heavy damage of NSCs to death, which are not the proper dosages for model establishment in this study. Therefore, dosage of $100 \mu \mathrm{M}$ was applied in the following experiments. With the morphology result (Figure 2(b)), the control NSCs displayed healthy cell morphology with bright and smooth cell body and extended neural synapses, while the injured NSCs by $100 \mu \mathrm{M} \mathrm{H}_{2} \mathrm{O}_{2}$ treatment demonstrated broken cytomembrane, wizened cell body, and synapses, indicating an unhealthy status. DCFDA staining demonstrated obviously more ROS production in $\mathrm{H}_{2} \mathrm{O}_{2}$ treatments NSCs, comparing to that in control NSCs (Figure 2(c)). While for Annexin V-FITC/PI assay (Figure 2(d)), 44\% of the $\mathrm{H}_{2} \mathrm{O}_{2}$ injured NSCs were positively stained by Annexin V-FITC indicating an early stage apoptosis, which was significantly higher than that with control NSCs at a normal level of 22\%; $20 \%$ of the injured NSCs demonstrated double staining by Annexin V-FITC and PI staining, also notably greater than that with the control NSCs at $6 \% ; 27 \%$ of the injured NSCs were stained by PI indicating later stage of cell death, while the proportion in control
NSCs was only $4 \%$. The assay demonstrated a $9 \%$ healthy cell proportion in the $\mathrm{H}_{2} \mathrm{O}_{2}$ treatments NSCs, comparing with which was significantly higher in control NSCs, up to $68 \%$ (Figure 2(e)).

Taken together, these results suggested a significant damage on in vitro cultured NSCs by $100 \mu \mathrm{M} \mathrm{H}_{2} \mathrm{O}_{2}$ treatment. The injury produced could be due to the oxidative stress induced apoptosis and cell death.

3.3. Oxidative Stress Triggered the Activation of HSP9O and $N F-\kappa B / p 65$. To address the underlying molecular mechanism of cell survival of NSCs from oxidative stress induced apoptosis and cell death, the role of HSP90 and NF- $\kappa \mathrm{B} / \mathrm{p} 65$ in the pathology was investigated.

With oxidative stress injury by $\mathrm{H}_{2} \mathrm{O}_{2}$ administration, the protein expression of HSP90 significantly boosted up to 1.7-fold higher than that in control NSCs (Figure 3(a)). Consistently, as immunofluorescence demonstrated, HSP90 displayed a mainly cytoplasmic distribution in control NSCs. The nucleus around expression was observed only within a small number of cells while a significant centralized expression of HSP90 around the nuclei was detected in greater number of the NSCs treated by $\mathrm{H}_{2} \mathrm{O}_{2}$ (Figure 3(b)). The results indicated an involvement of HSP90 in NSCs survival against oxidative stress injury.

As for $\mathrm{NF}-\kappa \mathrm{B} / \mathrm{p} 65$, the $\mathrm{H}_{2} \mathrm{O}_{2}$ administration induced significantly upregulation on both total p65 and nuclear phospho-p65, while the protein in control NSCs maintained on regular level (Figure 3(c)). The immunofluorescence also demonstrated an increased nuclear distribution of phosphop65 after $\mathrm{H}_{2} \mathrm{O}_{2}$ administration, comparing with control NSCs (Figure 3(d)). These data suggest a notable activation of NF$\kappa \mathrm{B} / \mathrm{p} 65$ in NSCs survival against oxidative stress injury. 


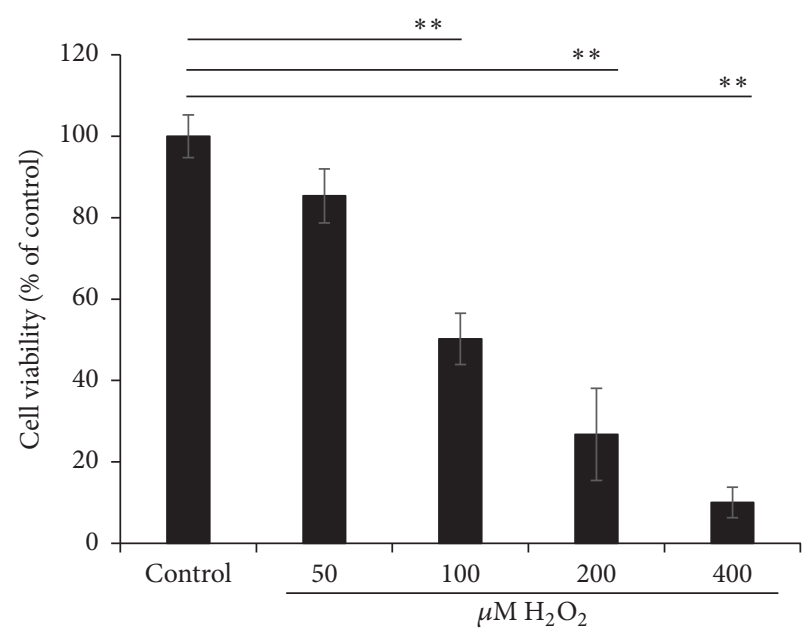

(a)

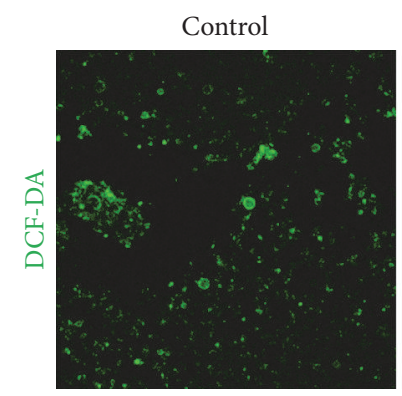

(c)
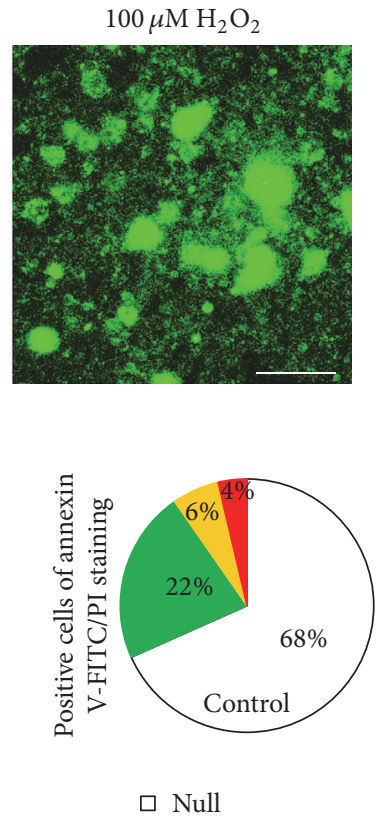

Annextin V+
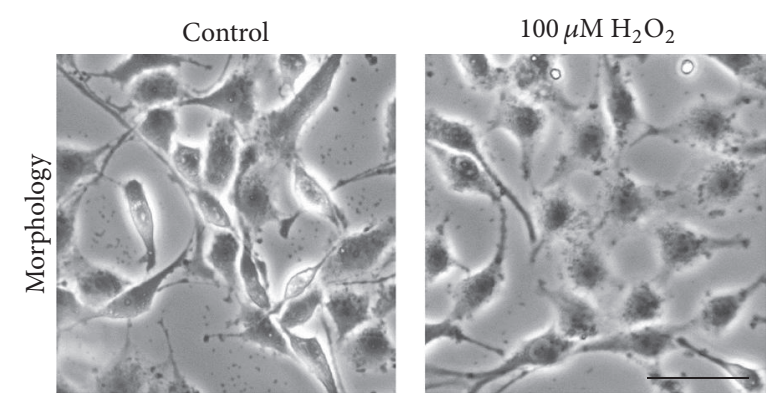

(b)
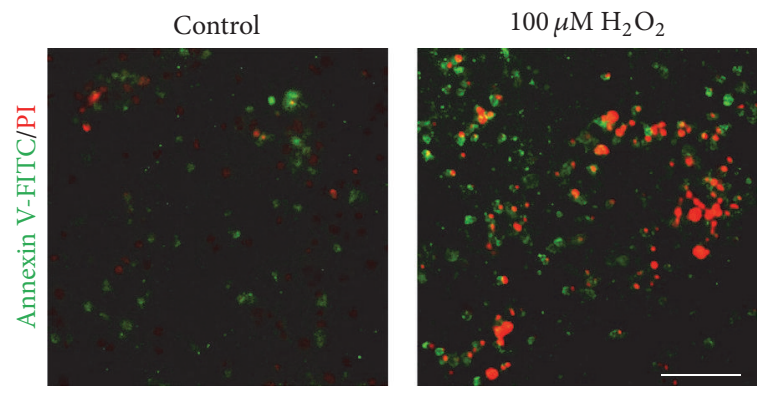

(d)

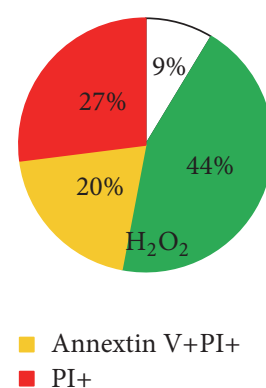

- PI+

(e)

FIGURE 2: NSCs survival from oxidative stress induced by $\mathrm{H}_{2} \mathrm{O}_{2}$ treatment. The NSCs were subjected to $100 \mu \mathrm{M} \mathrm{H}_{2} \mathrm{O}_{2}$ induction for $2 \mathrm{~h}$, following cell starving within the DMEM/F12 medium without B27, EGF, and bFGF. The NSCs treated with the vehicle medium were used as control. (a) The cell viability by MTT assay of the NSCs. (b) The cell morphology of the NSCs. (c) The ROS production of the NSCs probed by DCF-DA. (d) The apoptosis and cell death of the NSCs detected by Annexin V-FITC/PI kit. (e) Quantified positive cell number of the NSCs with Annexin V-FITC/PI staining. ${ }^{* *} P<0.01$ was considered to be significantly different between control and $\mathrm{H}_{2} \mathrm{O}_{2}$ groups.

3.4. Geldanamycin Blocked Oxidative Stress Triggered NF$\kappa B / p 65$ Activation. Since both HSP90 and NF- $\kappa$ B/p65 were involved in oxidative stressed injured NSCs, to determine their streaming relationship, pharmacological inhibitors targeting at the two signalling proteins were applied.

As the specific inhibitor of HSP90, the pretreatment of $0.5 \mu \mathrm{M}$ GA significantly abolished the $\mathrm{H}_{2} \mathrm{O}_{2}$-induced upregulation on phospho-IKK, phospho-I $\kappa \mathrm{B}$, and nuclear phosphor-p65, which suggested a deactivating effect on NF$\kappa \mathrm{B} / \mathrm{p} 65$ activation (Figures $4(\mathrm{a})-4(\mathrm{c})$ ).
3.5. JSH-23 Failed in Blocking the Oxidative Stress Triggered HSP90 Activation. While with the pretreatment $8 \mu \mathrm{M}$ JSH23 , the inhibitor of NF- $\kappa \mathrm{B} / \mathrm{p} 65$, the $\mathrm{H}_{2} \mathrm{O}_{2}$-induced upregulation on HSP90 in NSCs maintained with the augmented expression level [12], indicating a failed regulation of the NF- $\kappa \mathrm{B} / \mathrm{p} 65$ inhibitor on triggered HSP90 in oxidative stress injured NSCs (Figure 4(d)).

3.6. Induced Colocalization of HSP90 and NF- $\kappa B / p 65$ in Oxidative Stress Injured Neural Stem Cells. According to the 


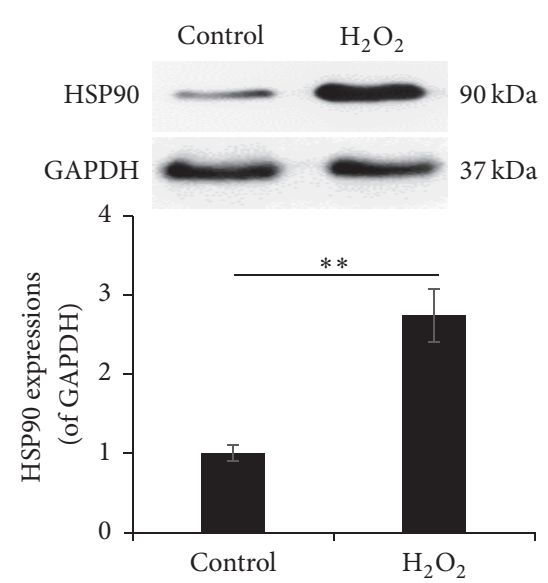

(a)

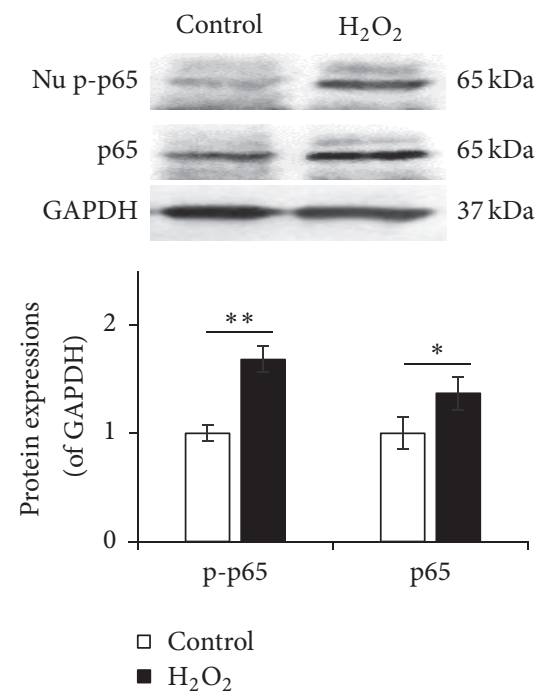

(c)
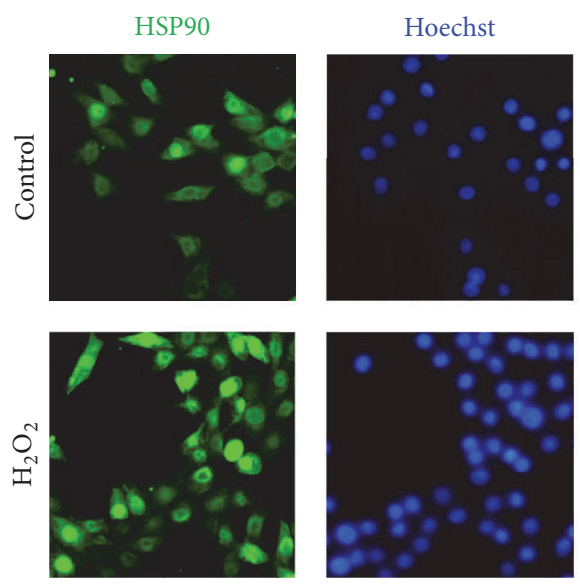

(b)
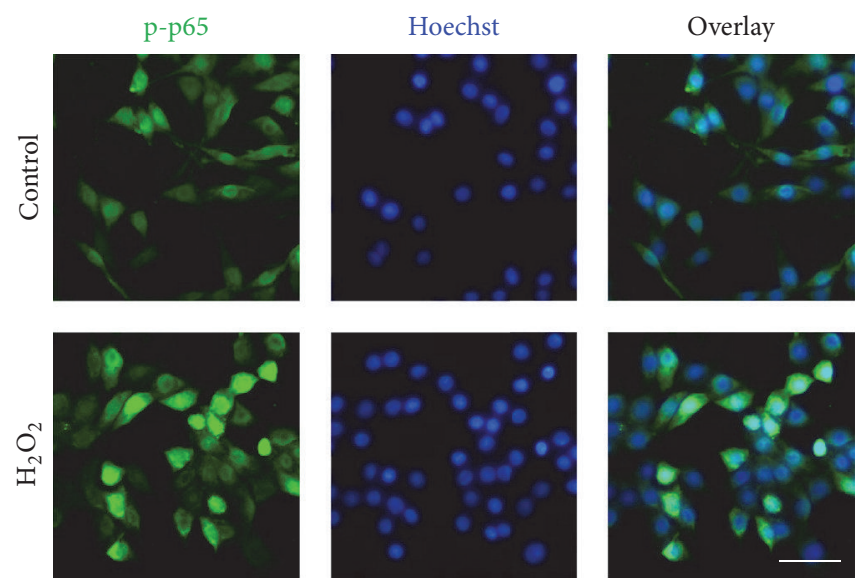

(d)

FIGURE 3: $\mathrm{H}_{2} \mathrm{O}_{2}$ triggers HSP90 and NF- $\kappa \mathrm{B} / \mathrm{p} 65$ activation. (a) and (c) The protein expression of HSP90, nuclear phospho-p65, and total p65 in the NSCs induced by $\mathrm{H}_{2} \mathrm{O}_{2}$ induction. (b) and (d) The intracellular distribution of HSP90 and the nuclear translocation of phospho-p65 in the $\mathrm{H}_{2} \mathrm{O}_{2}$ induced NSCs. The protein expression and intracellular distribution in NSCs cultured within the vehicle medium were used as control. ${ }^{*} P<0.05$ and ${ }^{* *} P<0.01$ were considered to be significantly different between control and $\mathrm{H}_{2} \mathrm{O}_{2}$ groups. $n=3$.

results from both inhibitors, HSP90 could potentially work as an upper-stream signalling over NF- $\kappa \mathrm{B} / \mathrm{p} 65$ in the survival of NSCs from $\mathrm{H}_{2} \mathrm{O}_{2}$-induced neural oxidative stress.

Further investigation with GA demonstrated that, in contrast with the cytoplasmic distribution of HSP90 and nuclear expression of p-p65 at a low level in control NSCs, the $\mathrm{H}_{2} \mathrm{O}_{2}$-injured NSCs displayed a dramatic upregulation on p-p65 nuclear translocation, as well as a significant augment on HSP90 and p-p65 colocalization at nuclei (Figure 5). This diploid activation on HSP90 and nuclear p-p65 under $\mathrm{H}_{2} \mathrm{O}_{2}$ induction in NSCs was obviously abolished by pretreatment of GA, the inhibitor of HSP90. The protein distribution of HSP90, especially around the nuclei, was attenuated, while the nuclear translocation of p-p65 was notably decreased. Therefore, the colocalization of HSP90 and p-p65 was partly abolished by GA pretreatment (Figure 5).
The results indicated that as far as HSP90 activity was inhibited by GA, NF- $\kappa \mathrm{B} / \mathrm{p} 65$ signalling was blocked as an effector. HSP90 activity performed as an upper-stream signalling of NF- $\kappa \mathrm{B} / \mathrm{p} 65$ under $\mathrm{H}_{2} \mathrm{O}_{2}$ induction.

\subsection{Protective Effect of Geldanamycin on Oxidative Stress} Injured Neural Stem Cells. With the determination of upperstream role of HSP90 over NF- $\kappa \mathrm{B} / \mathrm{p} 65$, we further mean to confirm the function of HSP90 in NSCs survival from oxidative stress induced cell death.

Both Hoechst/PI double staining and MTT assay demonstrated the neuroprotective effect of GA pretreatment against $\mathrm{H}_{2} \mathrm{O}_{2}$-injury. With the Hoechst straining as a cell count, the PI staining positive cells were considered as the damaged NSCs, whose number was obviously decreased with GA treatment, followed by $\mathrm{H}_{2} \mathrm{O}_{2}$-injury; the cell viability was 

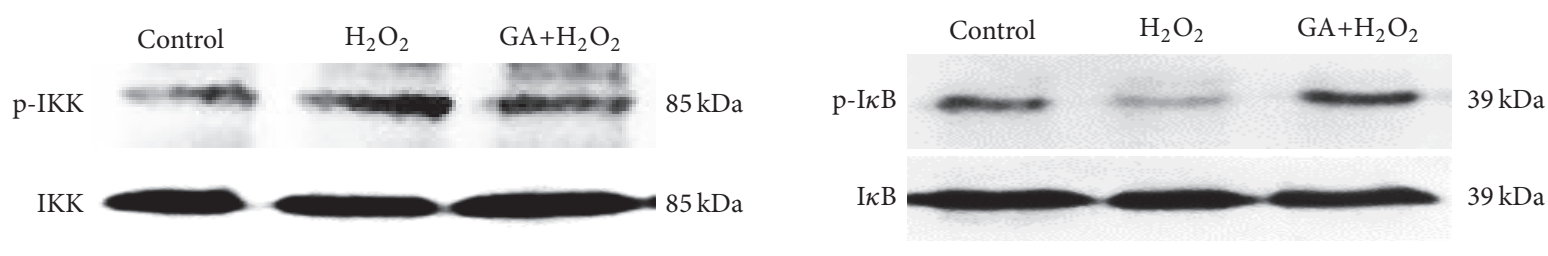

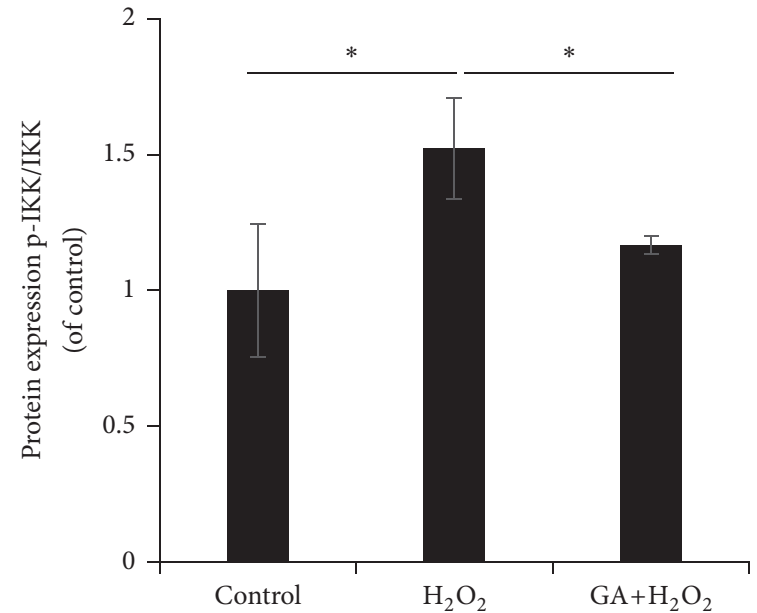

(a)

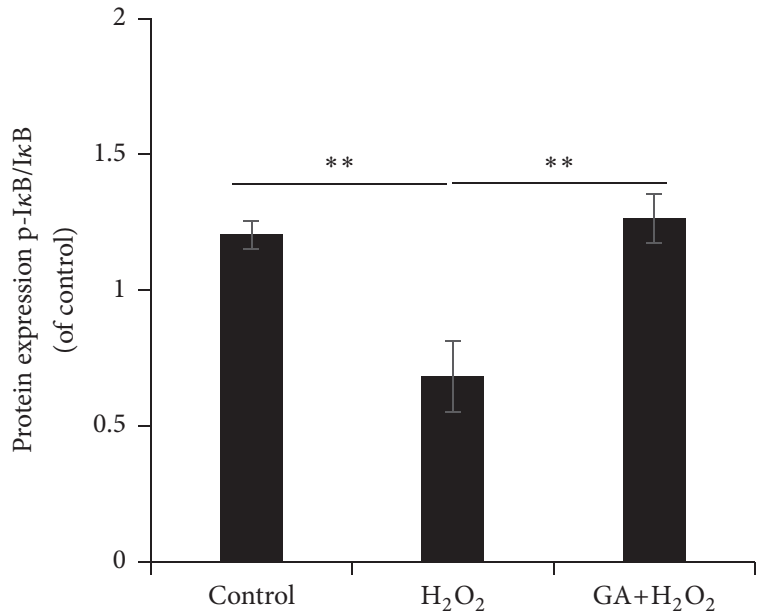

(b)
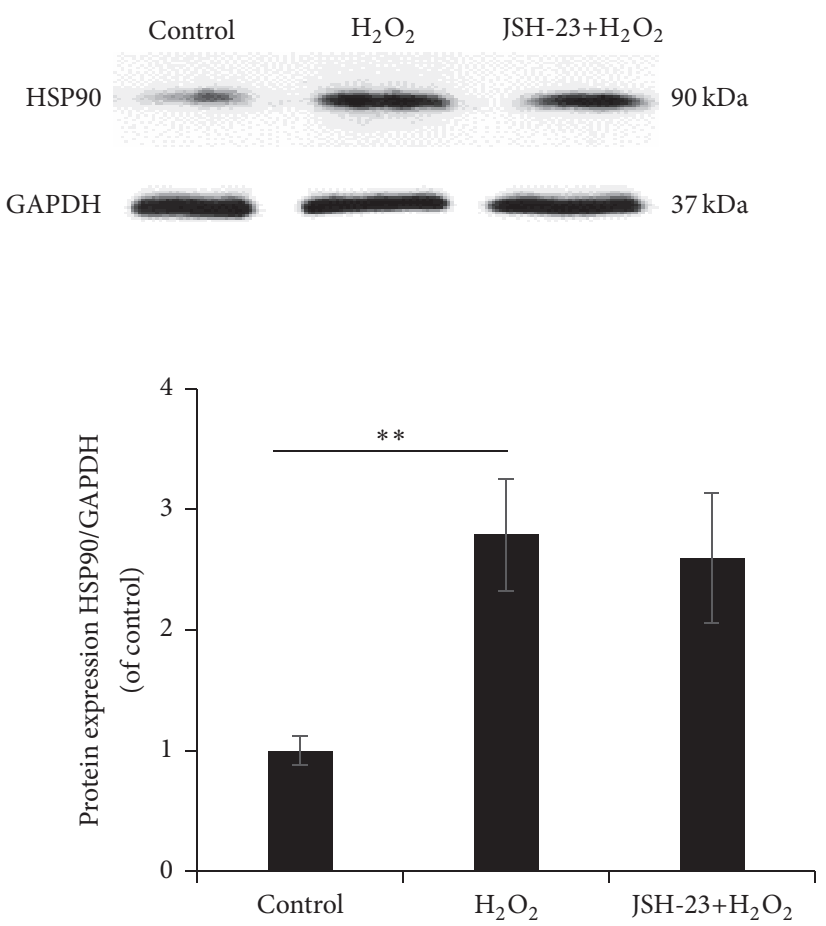

(d)

FIGURE 4: Effect of Geldanamycin and JSH-23 on $\mathrm{H}_{2} \mathrm{O}_{2}$ induced NF- $\kappa \mathrm{B} / \mathrm{p} 65$ and HSP90 activation. The pretreatment of $0.5 \mu \mathrm{M} \mathrm{GA}$ or $8 \mu \mathrm{M}$ JSH-23 was administrated to NSCs for $1 \mathrm{~h}$, followed by the $\mathrm{H}_{2} \mathrm{O}_{2}$ induction. (a)-(c) The protein expression of phospho-IKK, total IKK, phospho-I $\kappa \mathrm{B}$, total $\mathrm{I} \kappa \mathrm{B}$, nuclear phospho-p65, and total p65 in the NSCs treated with $\mathrm{GA}$ and $\mathrm{H}_{2} \mathrm{O}_{2}$. (d) The protein expression of HSP90 in the NSCs treated with JSH-23 and $\mathrm{H}_{2} \mathrm{O}_{2}$. The protein expression in NSCs cultured within the vehicle medium was used as control. ${ }^{*} P<0.05$ and ${ }^{* *} P<0.01$ were considered to be significantly different between control and $\mathrm{H}_{2} \mathrm{O}_{2}$ or between $\mathrm{H}_{2} \mathrm{O}_{2}$ and GA/JSH-23+ $\mathrm{H}_{2} \mathrm{O}_{2}$ groups. $n=$ 3. 

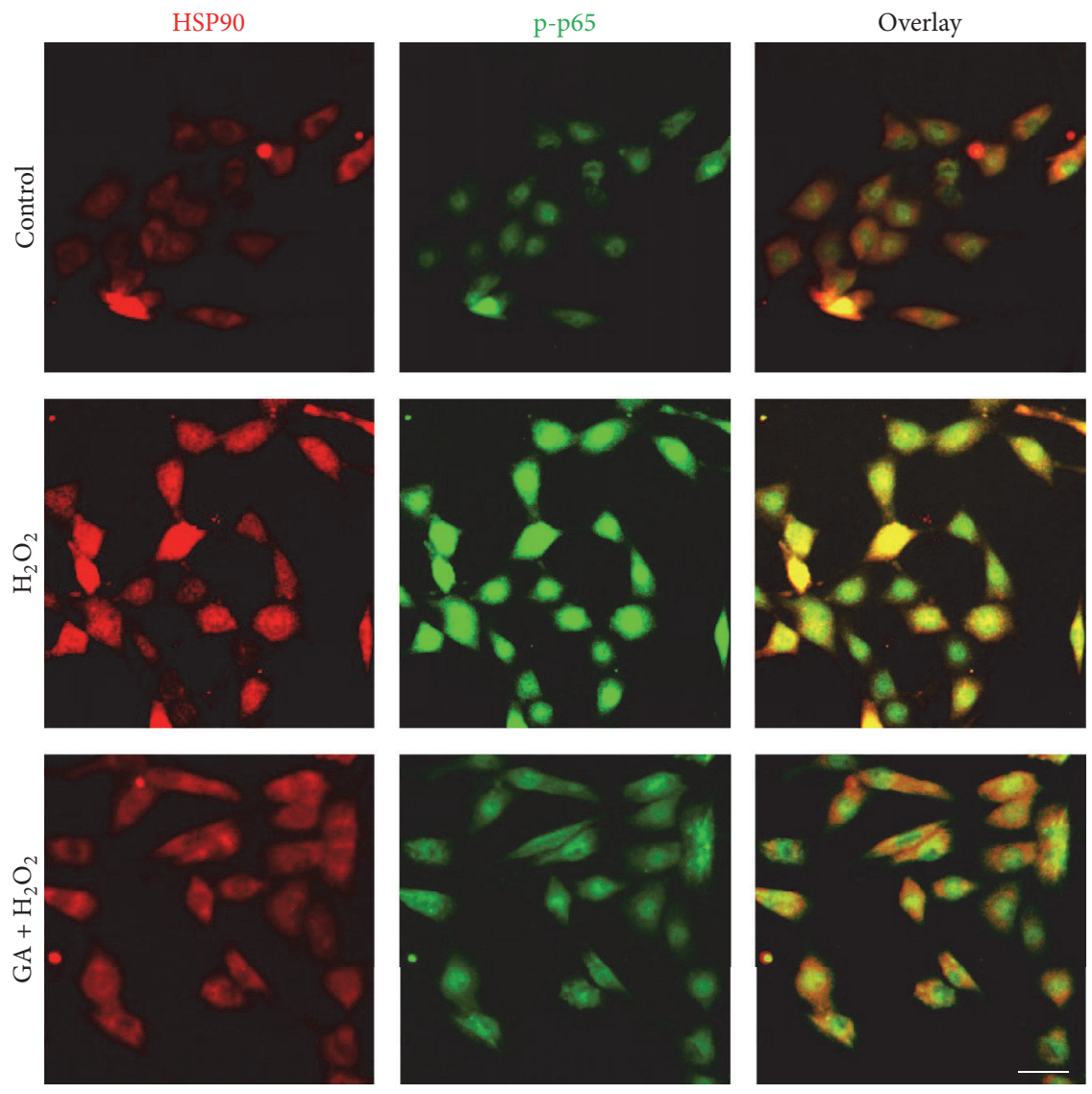

(a)

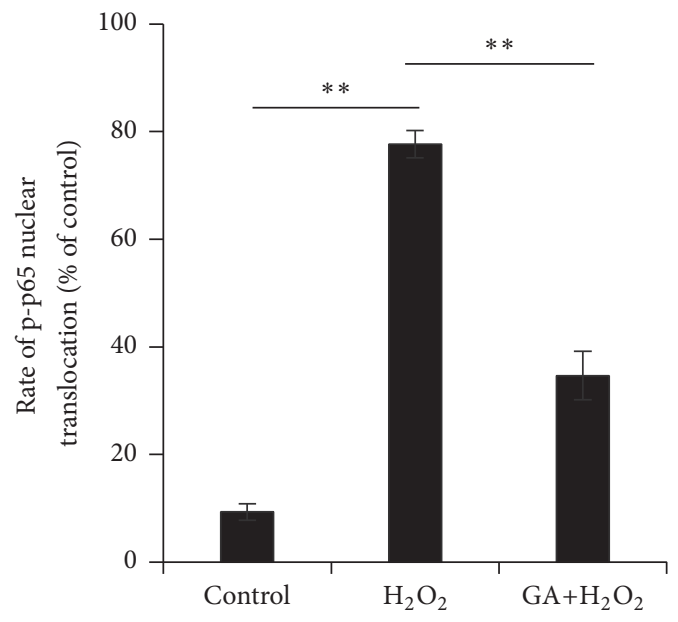

(b)

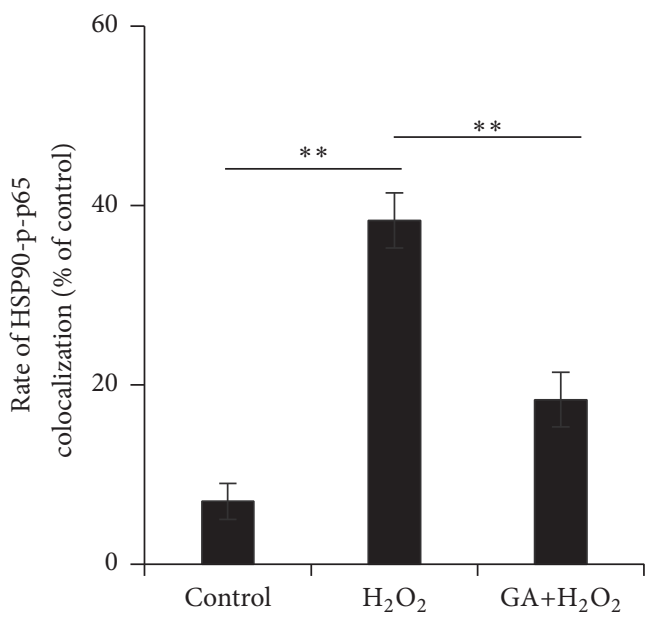

(c)

FIGURE 5: Effect of Geldanamycin on the colocalization in the $\mathrm{H}_{2} \mathrm{O}_{2}$ induced NSCs. (a) The protein distribution and colocalization of HSP90 and NF- $\kappa \mathrm{B} / \mathrm{p} 65$ in control, $\mathrm{H}_{2} \mathrm{O}_{2}$ induced, and GA $+\mathrm{H}_{2} \mathrm{O}_{2}$ induced NSCs. (b) Percentage of phospho-p65 nuclear translocation in control, $\mathrm{H}_{2} \mathrm{O}_{2}$ induced, and $\mathrm{GA}+\mathrm{H}_{2} \mathrm{O}_{2}$ induced NSCs. (c) Percentage of colocalization of HSP90 and NF- $\kappa \mathrm{B} / \mathrm{p} 65$ in control, $\mathrm{H}_{2} \mathrm{O}_{2}$ induced, and $\mathrm{GA}+\mathrm{H}_{2} \mathrm{O}_{2}$ induced NSCs. ${ }^{* *} \mathrm{P}<0.01$ was considered to be significantly different between control and $\mathrm{H}_{2} \mathrm{O}_{2}$ groups or between $\mathrm{H}_{2} \mathrm{O}_{2}$ and $\mathrm{DA}+\mathrm{H}_{2} \mathrm{O}_{2}$ groups. $n=3$.

rescued from $46.7 \pm 7.5 \%$ to $65.6 \pm 6.3 \%$ with GA treatment, in previous of $\mathrm{H}_{2} \mathrm{O}_{2}$-injury (Figure 6).

The results suggested a neuroprotection of inhibiting HSP90 with GA on NSCs survival from oxidative stress.

\section{Discussion}

As the stem cell transplantation arising as a potential therapy for serials of CNS disease [2], the cell survival of engrafted 


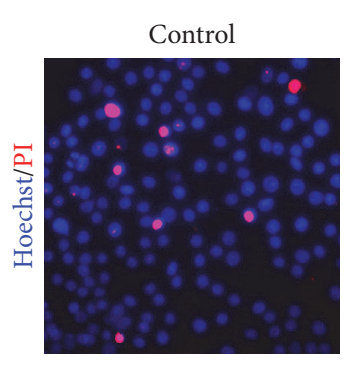

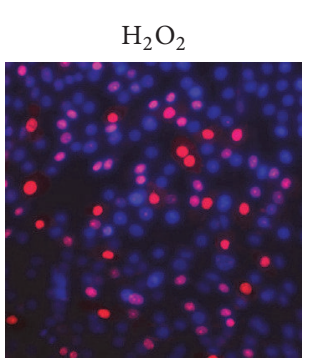

(a)
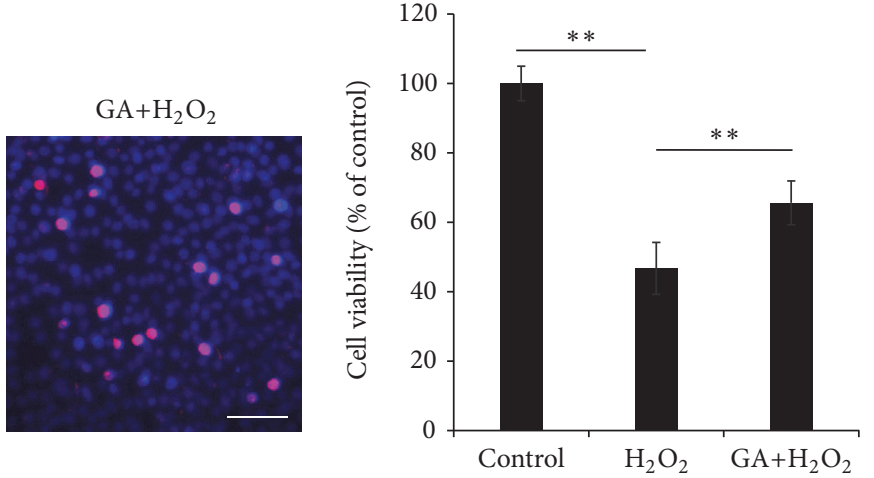

(b)

Figure 6: Effect of Geldanamycin on the $\mathrm{H}_{2} \mathrm{O}_{2}$ damaged NSCs. The pretreatment of $0.5 \mu \mathrm{M}$ GA was administrated to NSCs for $1 \mathrm{~h}$, followed by the $\mathrm{H}_{2} \mathrm{O}_{2}$ induction. The NSCs treated with the vehicle medium were used as control. (a) The cell death of each group of NSCs detected by Hoechst 33342/PI double staining. (b) The cell viability of each group of NSCs by MTT assay. ${ }^{* *} P<0.01$ was considered to be significantly different between control and $\mathrm{H}_{2} \mathrm{O}_{2}$ or between $\mathrm{H}_{2} \mathrm{O}_{2}$ and $\mathrm{DA}+\mathrm{H}_{2} \mathrm{O}_{2}$ groups. $n=3$.

stem cells after transplantation has become a vital limitation to the therapy outcome and further application [4]. The engrafted stem cells always face very complicated pathological condition, such as oxidative stress, inflammation, and immune response, among which oxidative stress could play a primary role $[9,13]$. A range of CNS pathologies, such as neurodegenerative diseases and neural trauma, are symbolized as oxidative stress, following the overbalanced ROS production $[6,9]$. The oxidative stress consequently induces the cell damage around the lesion area, as well as the engrafted stem cell. To overcome the neural oxidative stress and rescue the engrafted stem cell, investigation on the mechanism underlying stem cell survival from oxidative stress is quite needed. Our previous study has revealed that $\mathrm{H}_{2} \mathrm{O}_{2}$ could damage the neuronal cell line and PC12 cells at concentration of $400 \mu \mathrm{M}[10]$; the ischemia/reperfusion injury, of which oxidative stress plays a crucial role, causes different types of cell death on neurons, including apoptosis and autophagy [8]. However, the study on NSCs survival from $\mathrm{H}_{2} \mathrm{O}_{2}$-induced oxidative stress and its underlying mechanism have rarely been reported before. In this study, we modelled the oxidative stress injured NSCs with $100 \mu \mathrm{M} \mathrm{H}_{2} \mathrm{O}_{2}$ induction. The oxidative induction notably increased the ROS production, detected by DCF-DA probe method. And the induction damaged the NSCs to apoptosis, even cell death, mimicking the NSCs survival in pathological environment for transplantation therapy.

Concerning the involved signalling mechanism of neural injury by oxidative stress, NF- $\kappa \mathrm{B}$ is normally listed as the first candidate $[14,15]$. It was confirmed by our results that when induced oxidative stress happens in NSCs, NF- $\kappa \mathrm{B}$ is activated through $\mathrm{IKK} / \mathrm{I} \kappa \mathrm{B} / \mathrm{p} 65$ cascaded phosphorylation. The phospho-p65 in consequence is released from the complex with $\mathrm{I} \kappa \mathrm{B}$ and translocates into nucleus for relative gene transcription, which finally leads to DNA damage, signalling overactivation, and cell death. It can be considered that NF$\kappa \mathrm{B} / \mathrm{p} 65$ is involved in NSCs damage by oxidative. However, it is still too far away from concluding it as the very mechanism underlying the NSCs survival from oxidative stress.
We further move our focus to HSP90, a chaperone protein that facilities other proteins folding properly, stabilizes protein against stimulations, and rescues protein from degradation [16]. HSP90 is normally required for protein stabilization essential to tumour progress [16]. Therefore, the protein is always considered as a drug target for cancer therapy and research [17]. However, the function of HSP90 involved in neural damage and cellular oxidative stress is rarely reported wildly. Here, in this study, along with the activation of $\mathrm{NF}-\kappa \mathrm{B} / \mathrm{p} 65$ during the neural oxidative pathology, HSP90 was also triggered through upregulated protein expression and centralized distribution around nucleus. Moreover, the oxidative induced NSCs displayed an increased colocalization of HSP90 and NF- $\kappa \mathrm{B} / \mathrm{p} 65$, comparing to the normal control NSCs, which suggest a cofactor relationship between the two signalling proteins on mediating oxidative stress in NSCs [18]. Previous reports described the relationship in several other pathologies as a requirement of HSP90 for IKK biosynthesis and induced NF- $\kappa \mathrm{B}$ activation [19] or an inhibition on NF- $\kappa \mathrm{B} / \mathrm{p} 65$ by the HSP90 inhibitor [20]. To further determine the streaming relationship between the two signalling proteins, we applied their pharmacological inhibitor on each other. According to our results, the HSP90 inhibitor [21], GA, blocked the induced IKK/I $\kappa \mathrm{B} / \mathrm{p} 65$ activation, while the NF- $\kappa \mathrm{B} / \mathrm{p} 65$ inhibitor [12], JSH-23, failed in inhibiting HSP90 upregulation when oxidative stress happens in NSCs. It suggested an upper-stream role of HSP90 to NF- $\kappa \mathrm{B} / \mathrm{p} 65$ in NSCs oxidative stress. The requirement of HSP90 for NF- $\kappa \mathrm{B} / \mathrm{p} 65$ could not happen as late until p65 phosphorylation but potentially starts as early as $I K K$ and $I \kappa B$ activating stage, according to the effect of GA on the two upper-stream kinases of NF- $\kappa \mathrm{B} / \mathrm{p} 65$. The decreased nuclear translocation of phospho-p65 and attenuated colocalization of phospho-p65 and HSP90 by GA administration followed by oxidative injury, in consistency further confirming the role of HSP90 upon NF- $\kappa \mathrm{B} / \mathrm{p} 65$ activation under the pathology. As far as was determined by the relationship between HSP90 and NF- $\kappa \mathrm{B} / \mathrm{p} 65$ oxidative injury, our data using GA on NSCs suggested a rescuing effect 


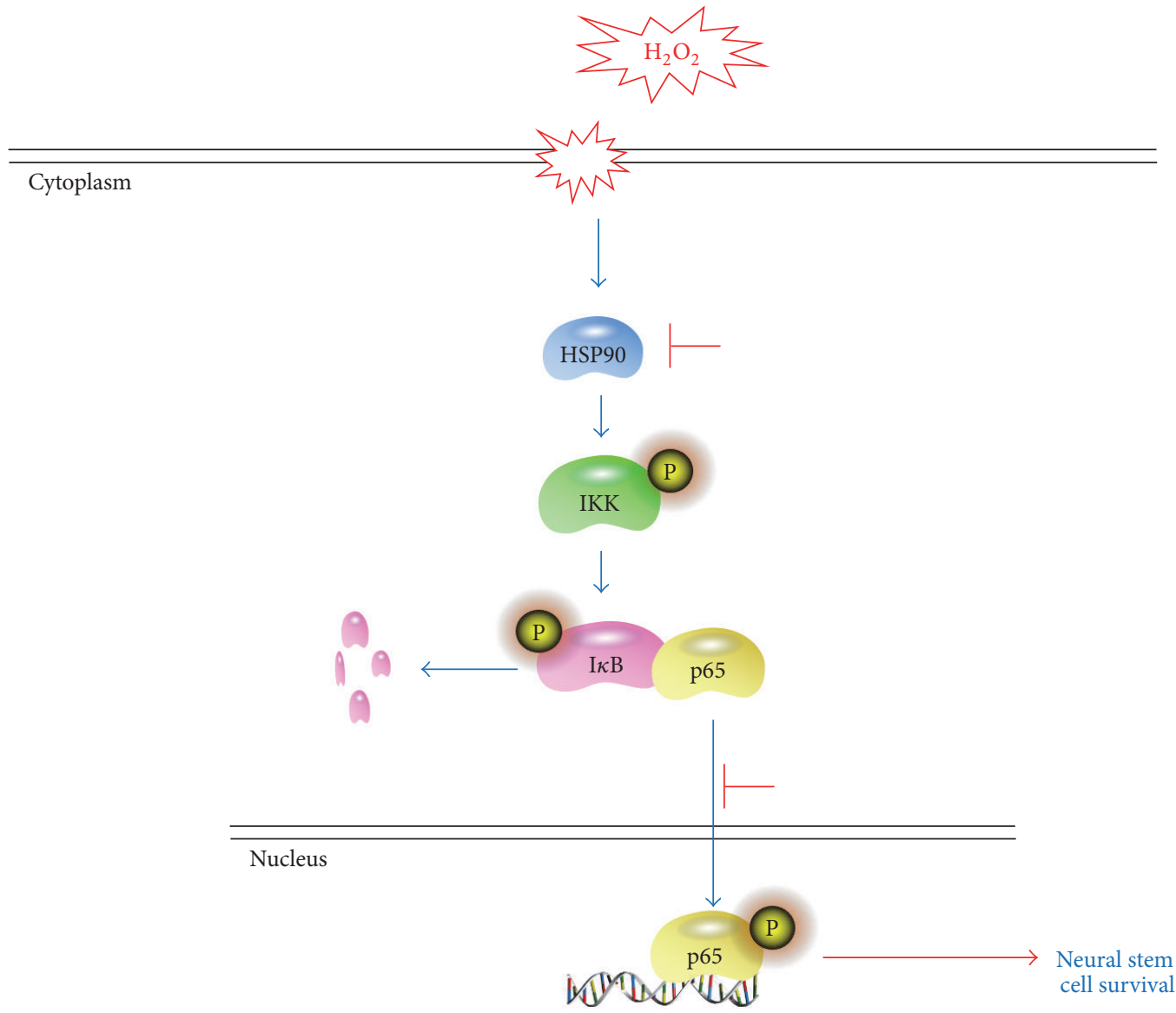

FIGURE 7: Diagram of HSP90/NF- $\kappa$ B pathway of NSCs survival from oxidative stress. The cell death inducing oxidative stress triggers HSP90 to activate IKK/I $\kappa \mathrm{B} / \mathrm{p} 65$ pathway and damage NSCs to apoptosis and death. The inhibition on HSP90 from neural oxidative induction will block the NF- $\kappa \mathrm{B} / \mathrm{p} 65$ signalling activation and rescue the NSCs from oxidative damage.

through HSP90 inhibition from oxidative stress induced cell death.

In conclusion, taking together the above results, it is believed that the cell death inducing oxidative stress could trigger $\mathrm{IKK} / \mathrm{I} \kappa \mathrm{B} / \mathrm{p} 65$ activation through HSP90 and induce NSCs damage. The inhibition on HSP90 activity from neural oxidative stress will block the NF- $\kappa \mathrm{B} / \mathrm{p} 65$ signalling activation and promote the NSCs survival (Figure 7). The protecting effect on NSCs in oxidative stress and its underlying signalling mechanism including HSP 90 and NF- $\kappa \mathrm{B} / \mathrm{p} 65$ that we reveal in this study provides some more data on NSCs survival from oxidative stress and also promotes the stem cell study and application on CNS pathology.

\section{Additional Points}

Highlights. (1) HSP90 and NF- $\kappa \mathrm{B} / \mathrm{p} 65$ activation are involved in oxidative stress induced NSCs damage. (2) HSP90 plays as an upper-stream signalling of NF- $\kappa \mathrm{B} / \mathrm{p} 65$ in NSCs survival from oxidative stress induced damage. (3) Inhibiting HSP90 promotes NSCs survival from oxidative stress induced damage through attenuating NF- $\kappa \mathrm{B} / \mathrm{p} 65$ activation.

\section{Competing Interests}

The authors declare that there is no conflict of interests regarding the publication of this article.

\section{Authors' Contributions}

Xinfeng Liu, Bing Song, and Qian Liu designed the experiment. Qian Liu, Yun Li, Wenkai Jiang, and Yunzi Li collected and analyzed the data. All authors contributed to the preparation of the manuscript.

\section{Acknowledgments}

This study was funded by Jiangsu Natural Science Foundation (no. BK20160607) to Qian Liu; National Natural Science Foundation (no. 81530038) to Xinfeng Liu; European Research Council StG Grant (no. 243261), Wellcome Trust Grant (WT082887) and the Royal Society URF Award (UF051616) to Bing Song; Jiangsu Provincial Special Program of Medical Science (no. BL2013025) to Xinfeng Liu; and the general financial grant from the China Postdoctoral Science Foundation (no. 201150M1571) to Qian Liu. 


\section{References}

[1] F. H. Gage and S. Temple, "Neural stem cells: generating and regenerating the brain," Neuron, vol. 80, no. 3, pp. 588-601, 2013.

[2] G. Martino and S. Pluchino, "The therapeutic potential of neural stem cells," Nature Reviews Neuroscience, vol. 7, no. 5, pp. 395406, 2006.

[3] B. A. Reynolds and S. Weiss, "Generation of neurons and astrocytes from isolated cells of the adult mammalian central nervous system," Science, vol. 255, no. 5052, pp. 1707-1710, 1992.

[4] Q. Wang, F. Duan, M.-X. Wang, X.-D. Wang, P. Liu, and L.-Z. $\mathrm{Ma}$, "Effect of stem cell-based therapy for ischemic stroke treatment: a meta-analysis," Clinical Neurology and Neurosurgery, vol. 146, pp. 1-11, 2016.

[5] M. Chomova and I. Zitnanova, "Look into brain energy crisis and membrane pathophysiology in ischemia and reperfusion," Stress, vol. 19, no. 4, pp. 341-348, 2016.

[6] P. M. Guedes, C. M. Andrade, D. F. Nunes et al., "Inflammation enhances the risks of stroke and death in chronic chagas disease patients," PLoS Neglected Tropical Diseases, vol. 10, no. 4, Article ID e0004669, 2016.

[7] D. M. Hermann, L. Peruzzotti-Jametti, J. Schlechter, J. D. Bernstock, T. R. Doeppner, and S. Pluchino, "Neural precursor cells in the ischemic brain-integration, cellular crosstalk, and consequences for stroke recovery," Frontiers in Cellular Neuroscience, vol. 8, article 291, 2014.

[8] D. Kong, J. Zhu, Q. Liu et al., "Mesenchymal stem cells protect neurons against hypoxic-ischemic injury via inhibiting parthanatos, necroptosis, and apoptosis, but not autophagy," Cellular and Molecular Neurobiology, 2016.

[9] R. Khatri, S. Krishnan, S. Roy, S. Chattopadhyay, V. Kumar, and A. Mukhopadhyay, "Reactive oxygen species limit the ability of bone marrow stromal cells to support hematopoietic reconstitution in aging mice," Stem Cells and Development, vol. 25, no. 12, pp. 948-958, 2016.

[10] Q. Liu, J.-P. Kou, and B.-Y. Yu, "Ginsenoside Rg1 protects against hydrogen peroxide-induced cell death in PC12 cells via inhibiting NF- $\kappa \mathrm{B}$ activation," Neurochemistry International, vol. 58, no. 1, pp. 119-125, 2011.

[11] Q. Liu, X. Fan, J. Zhu, G. Xu, Y. Li, and X. Liu, "Co-culturing improves the OGD-injured neuron repairing and NSCs differentiation via Notch pathway activation," Neuroscience Letters, vol. 559, pp. 1-6, 2014.

[12] A. Kumar, G. Negi, and S. S. Sharma, "JSH-23 targets nuclear factor-kappa B and reverses various deficits in experimental diabetic neuropathy: effect on neuroinflammation and antioxidant defence," Diabetes, Obesity and Metabolism, vol. 13, no. 8, pp. 750-758, 2011.

[13] T. Guan, Q. Liu, Y. Qian et al., "Ruscogenin reduces cerebral ischemic injury via NF- $\kappa \mathrm{B}$-mediated inflammatory pathway in the mouse model of experimental stroke," European Journal of Pharmacology, vol. 714, no. 1-3, pp. 303-311, 2013.

[14] J. E. Lee, M. S. Lim, J. H. Park, C. H. Park, and H. C. Koh, "Nuclear NF- $\kappa$ B contributes to chlorpyrifos-induced apoptosis through p53 signaling in human neural precursor cells," NeuroToxicology, vol. 42, pp. 58-70, 2014.

[15] Y. Qian, L. Cao, T. Guan et al., "Protection by genistein on cortical neurons against oxidative stress injury via inhibition of NF-kappaB, JNK and ERK signaling pathway," Pharmaceutical Biology, vol. 53, no. 8, pp. 1124-1132, 2015.
[16] L. H. Pearl, "Review: the HSP90 molecular chaperone-an enigmatic ATPase," Biopolymers, vol. 105, no. 8, pp. 594-607, 2016.

[17] A. Haque, Q. Alam, M. Z. Alam et al., "Current understanding of HSP90 as a novel therapeutic target: an emerging approach for the treatment of cancer," Current Pharmaceutical Design, vol. 22, no. 20, pp. 2947-2959, 2016.

[18] M. R. DeFee, Z. Qin, L. Dai, B. P. Toole, J. S. Isaacs, and C. H. Parsons, "Extracellular Hsp90 serves as a co-factor for NF- $\kappa \mathrm{B}$ activation and cellular pathogenesis induced by an oncogenic herpesvirus," American Journal of Cancer Research, vol. 1, no. 5, pp. 687-700, 2011.

[19] M. Broemer, D. Krappmann, and C. Scheidereit, "Requirement of Hsp90 activity for I $\kappa$ B kinase (IKK) biosynthesis and for constitutive and inducible IKK and NF- $\kappa \mathrm{B}$ activation," Oncogene, vol. 23, no. 31, pp. 5378-5386, 2004.

[20] K. Tago, F. Tsukahara, M. Naruse, T. Yoshioka, and K. Takano, "Hsp90 inhibitors attenuate effect of dexamethasone on activated NF- $\kappa$ B and AP-1," Life Sciences, vol. 74, no. 16, pp. 19811992, 2004.

[21] Z. Solarova, J. Mojzis, and P. Solar, "Hsp90 inhibitor as a sensitizer of cancer cells to different therapies (review)," International Journal of Oncology, vol. 46, no. 3, pp. 907-926, 2015. 


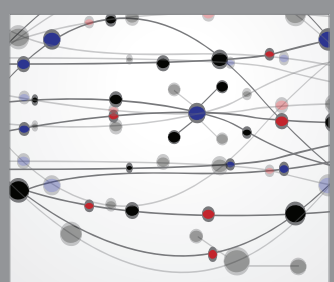

The Scientific World Journal
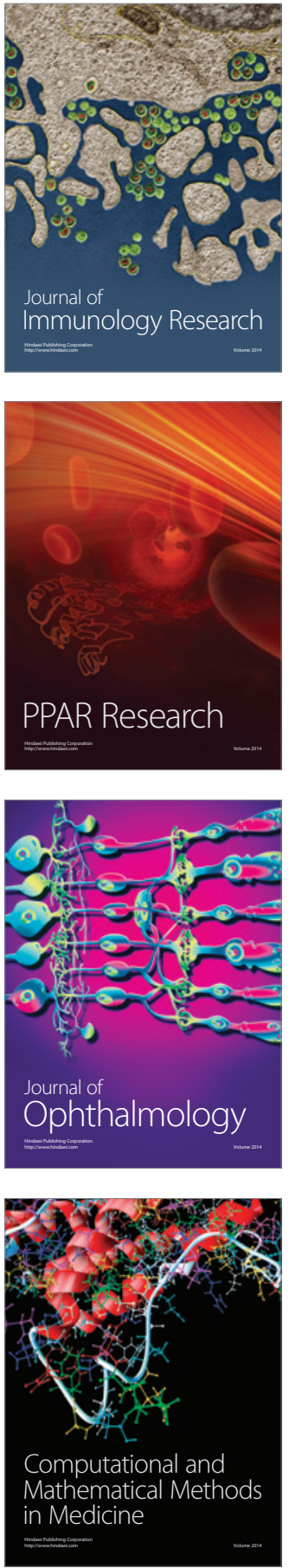

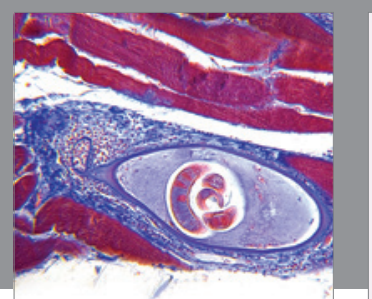

Gastroenterology Research and Practice

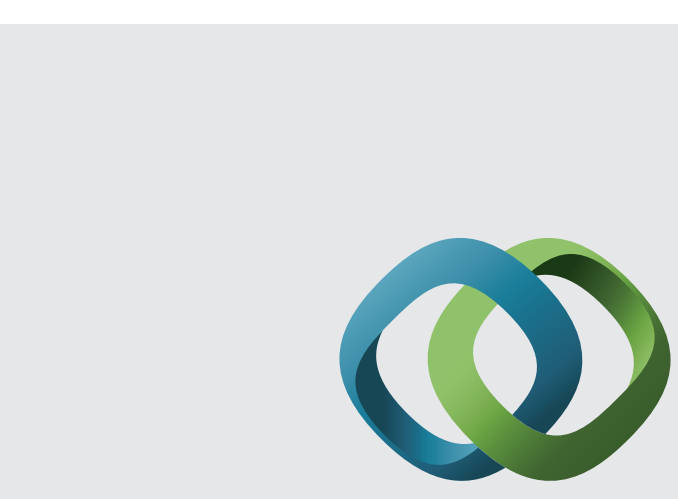

\section{Hindawi}

Submit your manuscripts at

http://www.hindawi.com
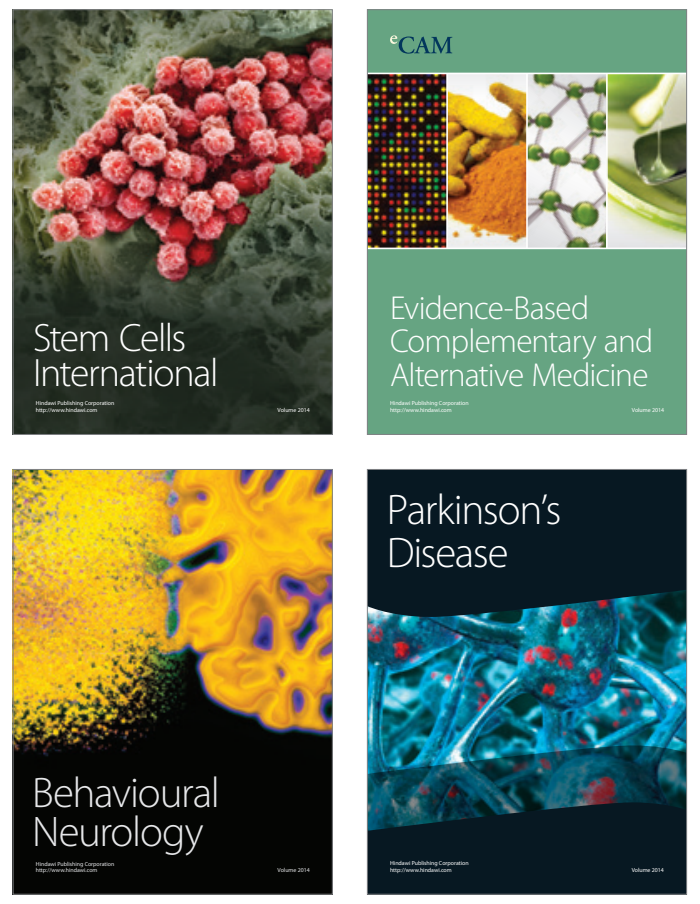
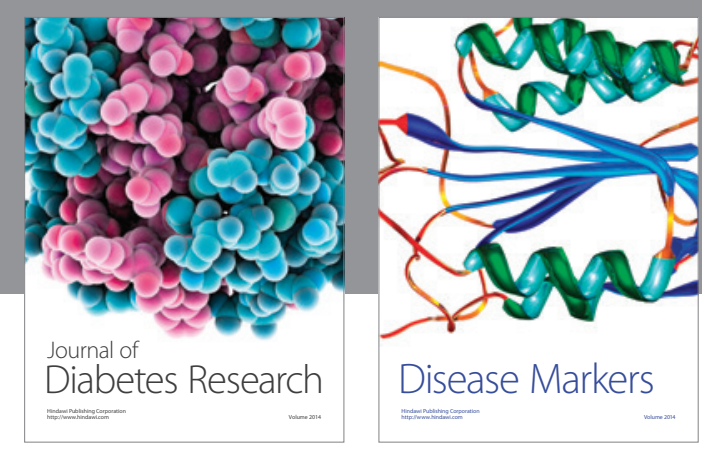

Disease Markers
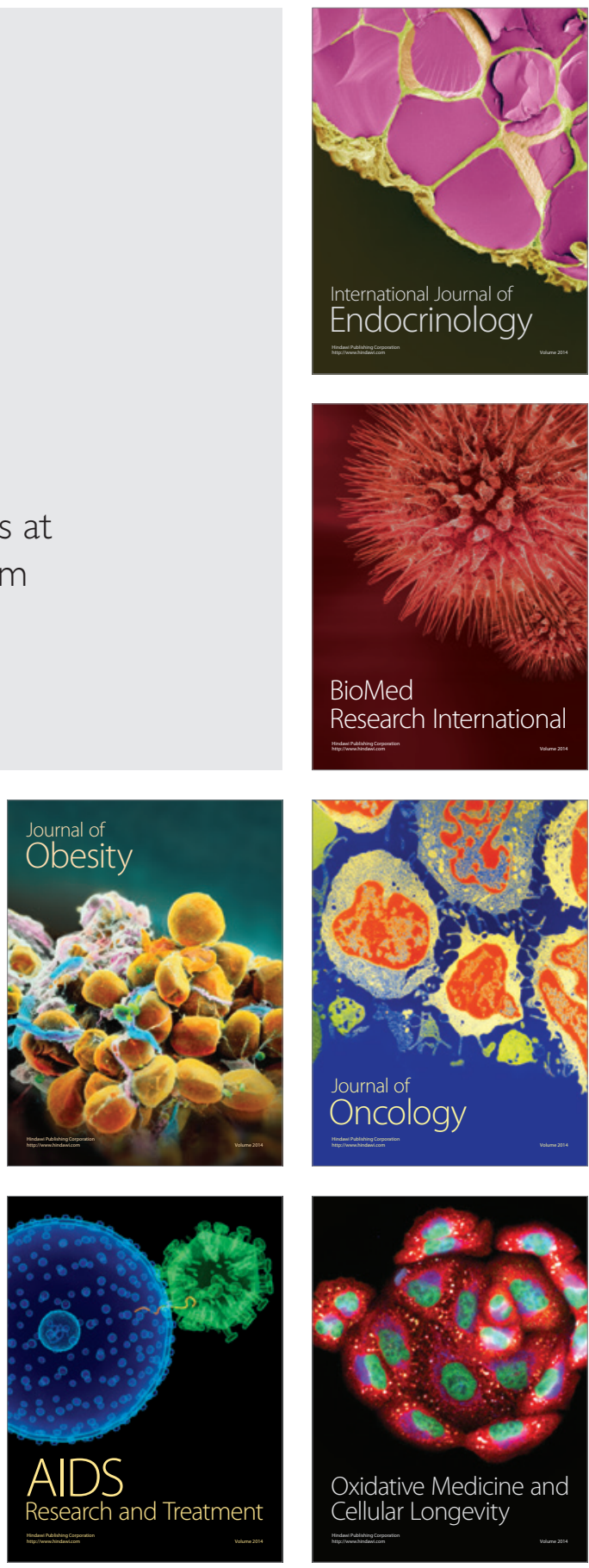